\title{
Use of compost bacteria to degrade cellulose from grass cuttings in biological removal of sulphate from acid mine drainage
}

\author{
MP Matshusa-Masithi' ${ }^{1}$, JS Ogola ${ }^{1}$ and L Chimuka ${ }^{2 *}$ \\ ${ }^{1}$ School of Environmental Sciences, University of Venda, P/Bag 5050, Thohoyandou, 0950, South Africa \\ ${ }^{2}$ School of Chemistry, University of Witwatersrand, P/Bag 3, Johannesburg, 2050, South Africa
}

\begin{abstract}
The study focused on the use of compost bacteria to degrade cellulose from grass cuttings as energy and carbon sources for sulphate-reducing bacteria (SRB) in a biological reactor. The fermentation of grass cuttings was carried out by anaerobic bacteria isolated from compost, thereby producing volatile fatty acids (VFA) and other intermediates, which were used as carbon and energy sources for sulphate reduction by SRB. Grass was added daily to the reactor in order to obtain maximum production of chemical oxygen demand (COD) and VFA. The results indicated that daily addition of grass is essential for the efficient VFA production, sulphate reduction and for the cell growth of the microbial biomass. Sulphate reduction of $38 \%$ was achieved with an average reactor chemical oxygen demand/sulphate $(\mathrm{COD} / \mathrm{SO})$ ratio of $0.56 \mathrm{mg} / \ell$. These results showed that $25 \mathrm{~g}$ of grass could produce enough VFA for a sulphate load of $25 \mathrm{~g}$, which is a cost-effective method for sulphate removal.
\end{abstract}

Keywords: sulphate, acid mine drainage, grass cuttings, volatile fatty acids, chemical oxygen demand and sulphate-reducing bacteria

\section{Introduction}

Acid mine drainage (AMD) is the name given to a polluted effluent from base metals, coal- and gold-mine waters. Mining industries produce effluents rich in sulphate, acid and metals due to the oxidation of sulphide minerals, especially pyrite $\left(\mathrm{FeS}_{2}\right)$. The exposure of $\mathrm{FeS}_{2}$ to oxygen and water results in the production of sulphate and ferrous ions (Eq.(1).

$$
2 \mathrm{FeS}_{2(\mathrm{~s})}+7 \mathrm{O}_{2}+2 \mathrm{H}_{2} \mathrm{O} \rightarrow 2 \mathrm{Fe}^{2+}+4 \mathrm{SO}_{4}{ }^{2-}+4 \mathrm{H}^{+}
$$

The ferrous iron produced is then converted to ferric ion, which is due to further oxidation by the acidophilic bacteria activity. The conversion of ferrous iron to ferric ion consumes one mole of acidity. This reaction is $\mathrm{pH}$ dependent with Eq. (2) proceeding slowly under acidic conditions ( $\mathrm{pH} 2$ to 3 ) and several orders of magnitude faster at $\mathrm{pH}$ values near 5 (Younger et al., 2002).

$$
4 \mathrm{Fe}^{2+}+\mathrm{O}_{2}+4 \mathrm{H}^{+} \rightarrow 4 \mathrm{Fe}^{3+}+2 \mathrm{H}_{2} \mathrm{O}
$$

The toxic metals, high salt concentrations and low $\mathrm{pH}$ in the AMD pose a major environmental threat through polluting water resources (Picavet et al., 2001). Ashton et al., (2002) projected a $100 \%$ increase in the use of water by the mining and industrial sectors from 1996 to 2030, which could imply an increase in the acid mine drainage problem in South Africa. Being aware of the danger of AMD to the environment, mitigation options could be used to prevent the contamination of streams, rivers and lakes by effluent discharge from the mines or to treat the contaminated water. This is a prerequisite for sustainable development.

\footnotetext{
To whom all correspondence should be addressed.

욜 +2711 717 6703; fax: +2711 7176749 ;

e-mail: 1uke.chimuka@wits.ac.za
}

Received 6 September 2007; accepted in revised form 2 October 2008.
This study has attempted to treat AMD biologically using an anaerobic, single-phase digestion and treatment system using the fermentation products of grass cuttings as carbon and energy sources. The use of biological sulphate removal technologies has been practised for years and is shown to compete successfully with other sulphate-removal technologies (Maree et al., 1985; Maree et al., 1986; Gottschalk, 1986). Biological sulphate removal technology requires the abundance of sulphate reducing bacteria (SRB) which require mesophilic temperatures and strict anaerobic conditions for the best performance (Greben et al., 2000). The competition for substrates by the SRB and other anaerobic bacteria also depends on the ratio of COD to the sulphate concentration of the wastewater (Hulshoff Pol et al., 1998). At a COD/sulphate ratio of $>0.67 \mathrm{mg} / \ell$, sufficient organic matter is present to completely reduce the available sulphate (Garcia et al., 2007). The SRB are generally less sensitive to $\mathrm{H}_{2} \mathrm{~S}$ produced as a result of sulphate reduction than other anaerobic bacteria (Oude Elferink et al., 1994; Greben et al., 2000).

Recently, Greben et al., (2007) explored the use of active biological sulphate reduction technology, so as to treat high volumes of acid mine-water. Bio-waste product used in this study was grass, which was degraded through fermentation, producing volatile fatty acids (VFA) from the cellulose components of grass. Bacteria isolated from rumen fluid were used for the fermentation process in order to produce polymers, monomers and other intermediates from cellulose material. The degradation products were then used as energy sources for the SRB. In this set-up, reactors were operated at 37 to $39^{\circ} \mathrm{C}$. In this study, we have investigated whether the same system could be operated at room temperature and still obtain similar results. We have also used bacteria isolated from compost at room temperature instead of from rumen fluid for the fermentation process. Any industrial process that can reduce energy needs is advantageous because of the shortages of energy supply worldwide and especially in South Africa as experienced by the current electricity load-shedding. 


\section{Materials and methods}

\section{Chemical preparations}

The chemicals of analytical reagent grade such as hydrochloric acid $(\mathrm{HCl})$, sodium bicarbonate $\left(\mathrm{NaHCO}_{3}\right)$ and magnesium sulphate $\left(\mathrm{MgSO}_{4} \cdot 7 \mathrm{H}_{2} \mathrm{O}\right)$ were used during the experiments. To make a $1 \mathrm{M}$ solution of $\mathrm{HCl}$, concentrated $\mathrm{HCl}(86 \mathrm{m \ell})$ was added to water $(800 \mathrm{~m} \ell)$ and diluted to a final volume of $1 \ell$. A 5\% magnesium sulphate was prepared by dissolving $5.0 \mathrm{~g}$ of magnesium sulphate in a $100 \mathrm{~m} \ell$ volumetric flask and was diluted to a final volume. $0.1 \mathrm{M}$ solution of $\mathrm{NaHCO}_{3}$ was prepared by dissolving $0.84 \mathrm{~g}$ of the salt in a 100 volumetric flask which was later diluted to the mark. Deionised water was used during the preparation of these solutions.

\section{Grass cuttings}

The Kikuyu grass cuttings (GC) used for studies 1 and 2 were stored at $4{ }^{\circ} \mathrm{C}$. Grass cuttings (GC) were obtained from CSIR Garden Services (Pretoria, South Africa). The length of the GC was 1 to $2 \mathrm{~cm}$. The weight of the grass in this study refers to air-dried grass. The moisture content of the $\mathrm{GC}$ was $7.6 \%$, while $1 \mathrm{~g} \mathrm{GC} / \ell$ corresponded with a COD concentration of $\approx 1 \mathrm{~g} / \ell$ (Greben et al., 2007).

\section{Inoculum preparation}

A sample of compost was taken from a compost heap and $1 \mathrm{~g}$ of this material was added to $5 \mathrm{~g}$ of straw suspended in $100 \mathrm{m \ell}$ hydroponics solution contained in a $250 \mathrm{~m} \ell$ conical flask. The flask was incubated at $30^{\circ} \mathrm{C}$ on a rotary shaker for 1 week. At time $\mathrm{t}_{0}$ (starting time), $18 \mathrm{~m} \ell$ of the resulting culture was used as inoculums for a bioreactor. This reactor had a culture volume of $750 \mathrm{~m} \ell$, contained in a $1000 \mathrm{~m} \ell$ cylindrical glass vessel with a screw cap that was equipped with a water trap. The irrigation medium of reactor was $0.5 \%(\mathrm{v} / \mathrm{v})$ molasses in water with a flow rate of $200 \mathrm{~m} \ell / \mathrm{d}$. The content of the reactor was continually mixed using a magnetic stirrer. Straw $(5 \mathrm{~g})$ was added to the reactor on a weekly basis after sampling. These inoculums were prepared at the Department of Microbiology, University of Stellenbosch.

\section{Experimental conditions}

\section{Study 1: Batch-operated reactors}

\section{Reactors}

Two anaerobic reactors (R10 and R100), each with a volume of $2000 \mathrm{~m} \ell$ were operated at room temperature and a controlled $\mathrm{pH}$ of 7.4 to create an environment for the compost microorganisms. The contents of the reactors were stirred by overhead stirrers.

\section{Operation of reactors}

Both reactors received $15 \mathrm{~m} \ell$ compost bacteria from the inoculums bioreactor, $300 \mathrm{~m} \ell \mathrm{SRB}, 5 \mathrm{~m} \ell$ nutrient solution and 2000 $\mathrm{mg} / \ell \mathrm{SO}_{4}$. The sulphate concentration of $2000 \mathrm{mg} / \ell$ was added at the beginning of the experiment and on days when the concentration was $<500 \mathrm{mg} / \ell$. Both reactors were operated for a period of $24 \mathrm{~d}$. Reactor R100 received $100 \mathrm{~g}$ grass cuttings once off, whereas reactor $\mathrm{R} 10$ received $10 \mathrm{~g}$ grass cuttings daily after taking a sample. Reactors were operated at room temperature.

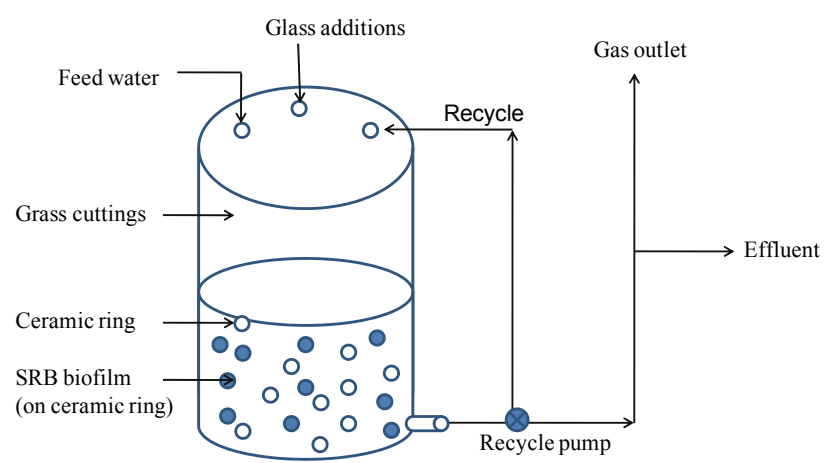

Figure 1

Schematic overview of one-stage reactor system

\section{Study 2: Continuously operated reactor}

Having studied the parameters that affect the biological sulphate removal in batch reactors, a one-stage continuous reactor was operated. This was to study the optimised parameters in a continuously fed one-stage reactor, with a volume of $10 \ell$ (Fig. 1). An effluent column of volume $7 \ell$ was added to control the outflow of the reactor. An aluminium stirrer was set to stir for 5 minutes per hour. The reactor inflow rate was $10 \ell / d$ resulting in a retention time of 1 day. The one-stage anaerobic reactor consisted of a fermentation section and a sulphate removal section. Artificial feed water resembling AMD has been described by Greben et al., (2007). This contained a $\mathrm{SO}_{4}$ concentration of $\approx 2500 \mathrm{mg} / \ell,\left(\mathrm{Na}_{2} \mathrm{SO}_{4}\right.$, Crest Chemicals, Johannesburg) as well as a macro-nutrient solution $(6.5 \% \mathrm{~N}, 2.7 \% \mathrm{P}, 13.0 \% \mathrm{~K}, 7.0 \% \mathrm{Ca}$, $2.2 \% \mathrm{Mg}$ and $7.5 \% \mathrm{~S})$ and micro-nutrient, solution $(0.15 \% \mathrm{Fe}$, $0.024 \% \mathrm{Mn}, 0.024 \% \mathrm{~B}, 0.005 \% \mathrm{Zn}, 0.002 \% \mathrm{Cu}$ and $0.001 \% \mathrm{Mo}$ ) of which $1 \mathrm{m \ell} / \ell$ feed water was, used respectively. The $\mathrm{pH}$ of the synthetic water was an average $\mathrm{pH}$ of 7.4. The bottom part of the reactor contained pumice stones as support material for SRB biofilm formation. Two litres SRB with a VSS of $3000 \mathrm{mg} / \ell$ and isolated anaerobic compost bacteria $(1 \ell)$ were added to the lower and upper part of the reactor, respectively. The upper part also received $160 \mathrm{~g}$ grass cuttings.

The one-stage reactor was operated under anaerobic conditions and at room temperature $\left(24\right.$ to $\left.25^{\circ} \mathrm{C}\right)$. Cellulose fermentation took place in the upper part of the reactor thereby producing VFA. Grass cuttings ( $25 \mathrm{~g}$ ) were added on a daily basis to obtain maximum VFA production. The reactor was fed continuously with artificial feed water for a period of 65 days. The feed water was the transport medium for the products from the upper part of the reactor to the lower part where sulphate reduction had to occur (Fig. 1).

\section{Analytical determinations}

The analytical method for determination parameters have been described by Greben et al., 2007. In brief, determination of sulphate, COD, pH, mixed liquor suspended solids (MLSS) and VSS were carried out according to standard analytical procedures as described in Standard Methods (1985). All analyses were carried out on filtered samples (Whatman \#1) with the exception of the MLSS, VSS and sulphide (How were these analysed). The COD samples were pretreated to eliminate the sulphide contribution to the COD concentration. All VFA analyses were done using a gas chromatograph (Hewlett Packard, HP 5890 Series II) equipped with a flame ionisation detector (FID). The column 


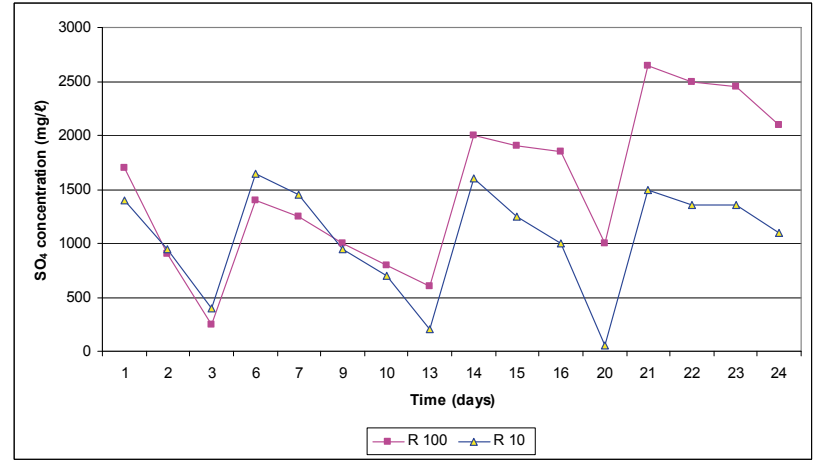

Figure 2

Sulphate reduction in $R 10$ and $R 100$

used was a HP-FFAP, $15 \mathrm{~m}$ x $0.53 \mathrm{~mm}$ internal diameter and $1 \mu \mathrm{m}$ film thickness. The GC/FID programme can be summarised as follows: initial oven temperature $30^{\circ} \mathrm{C}$, for $2 \mathrm{~min}$, temperature programmed to increase thereafter from $80^{\circ} \mathrm{C}$ to $200^{\circ} \mathrm{C}$ at $25^{\circ} \mathrm{C} / \mathrm{min}$, with temperature hold for $1 \mathrm{~min}$ at $200^{\circ} \mathrm{C}$ and FID temperature $240^{\circ} \mathrm{C}$. The carrier gas $\left(\mathrm{N}_{2}\right)$ flow rate was set at $1 \mathrm{m \ell} / \mathrm{min}$.

\section{Results and discussion}

\section{Study 1: Effect of daily addition of grass cuttings on the VFA concentration}

\section{Sulphate reduction}

Initially, the reduction of $\mathrm{SO}_{4}$ was similar in both reactors as shown in Fig. 2. $\mathrm{SO}_{4}$ was reduced from a concentration of $2000 \mathrm{mg} / \ell$ to $50 \mathrm{mg} / \ell$ within $3 \mathrm{~d}$ of operation. After Day 10 , the $\mathrm{SO}_{4}$ reduction became more prominent in $\mathrm{R} 10$, removing the freshly added $\mathrm{SO}_{4}$ faster, thus by Day 13 the $\mathrm{SO}_{4}$ concentrations increased to $200 \mathrm{mg} / \ell$ and $550 \mathrm{mg} / \ell$. From Day 13 to 14 , there was an abrupt increase of $\mathrm{SO}_{4}$ in $\mathrm{R} 10$; however, from day 14 to 20 , there was a continuous reduction in $\mathrm{R} 1$, whereas in $\mathrm{R} 100$ it was slower (Fig. 2), thus on Day 20, the $\mathrm{SO}_{4}$ concentrations were $<100 \mathrm{mg} / \ell$ and $1000 \mathrm{mg} / \ell$, respectively. These differences in the efficiency of sulphate removal between the two reactors can be explained by the fact that in the R10 reactor, grass cuttings were added on a daily basis thus providing enough available VFA and other intermediates of cellulose degradation, such as hydrogen present in the reactor, whereas R100 received grass cuttings once off. These findings are consistent with those of Greben et al. (2007). However, comparing the rate of sulphate removal in the batch studies at a temperature of 24 to $25^{\circ} \mathrm{C}$ with compost bacteria in this study to that by Greben et al. (2007) where the reactor was operated at 37 to $40{ }^{\circ} \mathrm{C}$ with rumen bacteria, it was shown that the sulphate removal rate was slightly higher in this study. $\mathrm{SO}_{4}$ was reduced from a concentration of $2000 \mathrm{mg} / \ell$ to $50 \mathrm{mg} / \ell$ within $3 \mathrm{~d}$ of operation while in Greben et al. (2007) it was reduced to less than $800 \mathrm{mg} / \ell$ in $11 \mathrm{~d}$.

\section{COD concentration}

The concentration of COD in the R10 was initially lower than in R100 (Fig. 3). This was because R100 started with a higher amount of grass cuttings which resulted in a higher COD concentration. During Day 14, the COD concentrations in both reactors were similar. When the COD concentration in R100 decreased, the opposite occurred in R10. This was due to the daily addition of $10 \mathrm{~g}$ of grass cuttings, which resulted in a continuously higher

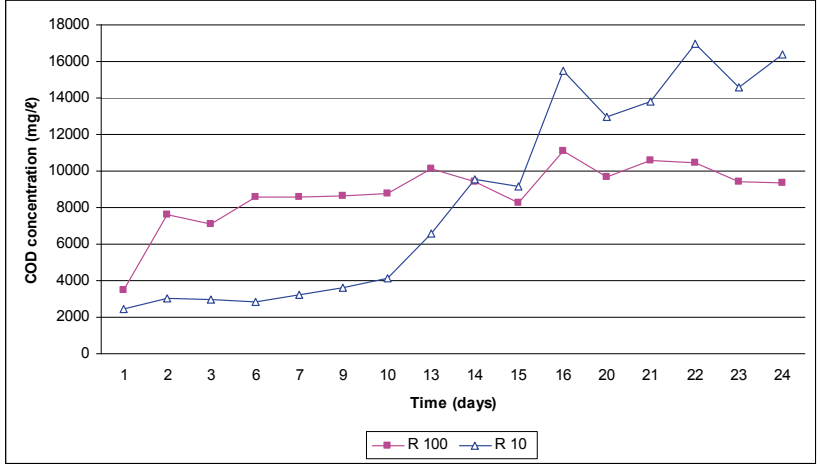

Figure 3

$C O D$ concentration (filtered) in the reactors $R 10$ and $R 100$

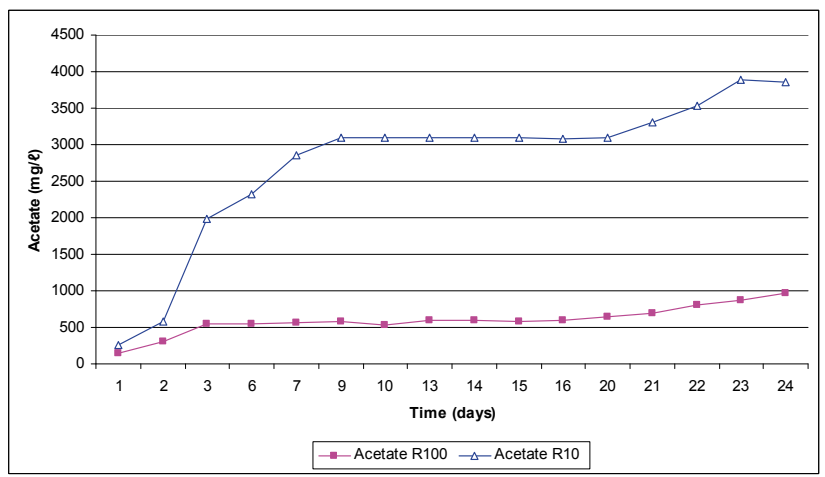

Figure 4

Acetate concentration in the reactors $R 100$ and $R 10$

COD concentration due to cellulose degradation by the compost bacteria.

\section{VFA concentration}

The acetate concentration in R100 increased to just over 500 $\mathrm{mg} / \ell$ up to Day 21 (Fig. 4). When the propionic and butyric acids increased on Days 22 to 24 (Fig. 5) the acetate concentration also increased to almost $1000 \mathrm{mg} / \ell$. This indicated that, due to a lower sulphate reduction, less butyrate was utilised and therefore less acetate was produced when compared to the R10 reactor. The acetate concentration in R10 increased from about $100 \mathrm{mg} / \ell$ to $>3500 \mathrm{mg} / \ell$ (Fig. 4) thus indicating that this reactor where daily grass cuttings were added was more efficient in sulphate removal. The increase of acetate concentration can thus be attributed to the acetate production from the grass cuttings and mainly from the utilisation of the propionic and butyric acids by the SRB. Equations (3) and (4) show the formation of acetate from propionic and butyric acids.

Figure 5 shows that in R10 reactor, propionic acid was being utilised. Further, the figure shows that more butyric acid was being produced than was being used for the sulphate reduction. The results seemed to indicate that the SRB utilised propionic acid more readily than butyric acid for $\mathrm{SO}_{4}$ reduction. This means that acetate was produced principally from butyrate utilisation, in which 1 mole of butyric acid produced 2 moles of acetate and propionate produced 1 mole of acetate (Eqs. (3) and (4)):

$$
\begin{aligned}
& \mathrm{CH}_{4} \mathrm{CH}_{2} \mathrm{CH}_{2} \mathrm{COO}^{-}+1 / 2 \mathrm{SO}_{4}^{2-} \\
& \rightarrow 2 \mathrm{CH}_{3} \mathrm{COO}^{-}+1 / 2 \mathrm{HS}^{-}+1 / 2 \mathrm{H}^{+}
\end{aligned}
$$




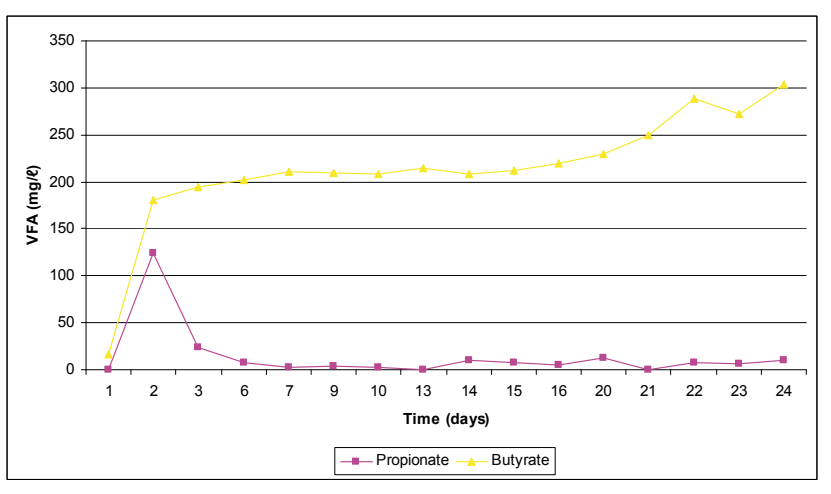

Figure 5

Propionic and butyric acid concentration in the reactor $R 10$

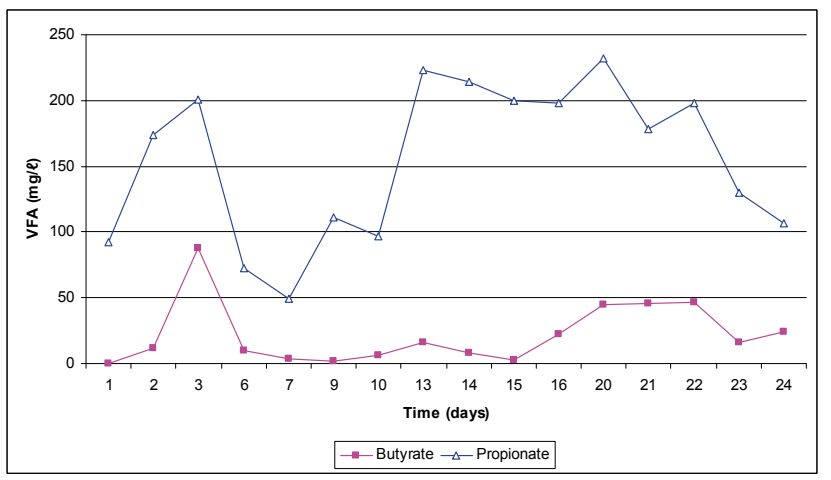

Figure 6

Propionic and butyric acid concentration in the reactor $R 100$

$$
\begin{aligned}
& \mathrm{CH}_{3} \mathrm{CH}_{2} \mathrm{COO}^{-}+3 / 4 \mathrm{SO}_{4}^{2-} \\
& \rightarrow \mathrm{CH}_{3} \mathrm{COO}^{-}+\mathrm{HCO}_{3}^{-}+3 / 4 \mathrm{HS}^{-}+1 / 4 \mathrm{H}^{+}
\end{aligned}
$$

In reactor $\mathrm{R} 100$, good sulphate reduction occurred till about Day 10 (Fig. 6). During that period most of the butyrate was utilised. After Day 10 the sulphate reduction continued, but at a slower rate. The butyrate concentration in the reactor was still about $200 \mathrm{mg} / \ell$ and was not as rapidly utilised as at the beginning of the experiment.

The above results on the production and utilisation of VFA are consistent with a previous study (Greben et al., 2007). It is known that when grass-cellulose is degraded by fermenting bacteria, short-chain VFA as well as methane are produced. Hydrogen produced in the presence of sulphate and SRB will typically be used as the preferred energy source by the SRB to such an extent that the SRB will outcompete the methanogenic bacteria (MB) for the available $\mathrm{H}_{2}$ (Visser, 1995 as cited by Greben et al., 2007). The preference of SRB for the above compounds can thus be arranged in the following decreasing order; hydrogen $>$ propionate $>$ butyrate $>$ acetate (Greben et al., 2007). This means that with sufficient hydrogen, propionic and butyric acids available for the SRB, acetic acid will not be utilised for the biological sulphate reduction, which can explain the steady increase in acetic acid and butyric acid concentrations in Figs. 4 and 5 , respectively. As shown in Fig. 6 propionic acid was not utilised efficiently compared to butyric acid despite it being preferred by the SRB. This can be attributed to the fact that it could have been produced more than needed by the SRB especially between Day 10 and 22 .

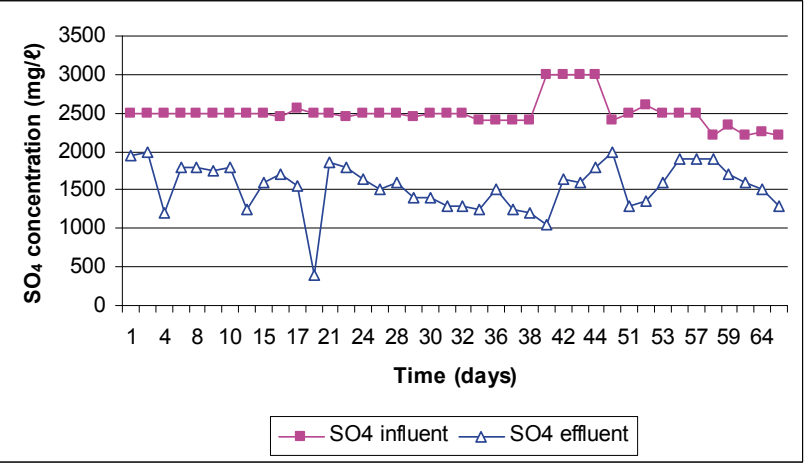

Figure 7

$\mathrm{SO}_{4}$ concentration in the influent and effluent of the reactor

\section{Study 2: Biological sulphate removal in a one-stage continuous reactor}

\section{$\mathrm{SO}_{4}$ influent and effluent of the reactor}

The reactor received a $\mathrm{SO}_{4}$-rich influent of $2500 \mathrm{mg} / \ell$ for $56 \mathrm{~d}$ after which it was decreased slightly in order to observe the effect on $\mathrm{SO}_{4}$ reduction with a lowered feed concentration (Fig. 7). The performance of the continuous reactor is also summarised in Tables 1 and 2.

On average, $\mathrm{SO}_{4}$ removal of $38 \%$ was obtained, although there was a day when the reduction reached $84 \%$, following the addition of fresh compost bacteria (CB) (Table 2). However, the mode of $\mathrm{SO}_{4}$ removal was $48 \%$ indicating that the reactor was almost nearly treating half the $\mathrm{SO}_{4}$ in the influent (Table 2). Out of $25 \mathrm{~g} / \mathrm{d} \mathrm{SO}_{4}$ fed into the reactor, a mean of $10 \mathrm{~g} / \mathrm{d}$ was removed. The percentage sulphate removal in the one-stage continuous reactor was almost half obtained in the previous study where rumen bacteria were used to degrade grass cuttings (Greben et al., 2007). In the previous study, mean sulphate removal of $86 \%$ was obtained (Greben et al., 2007). Some of the reasons why this reactor did not perform well with compost bacteria used to degrade cellulose can be explained when looking at the other parameters such as $\mathrm{COD} /$ sulphate ratio, $\mathrm{pH}$ of the treated, etc. These aspects are discussed below in detail.

\section{$\mathrm{COD} / \mathrm{SO}_{4}$ ratio in a reactor effluent}

Cellulose from grass cuttings provides a suitable source of carbon and energy for the SRB to be able to reduce sulphate. Hungate (1966) indicated that with suitable fermentation bacteria, cellulose can be degraded and fermented to VFA and other intermediates. The cellulose consists mainly of polymerised hexose, which can be degraded by natural occurring bacteria such as compost bacteria (Kalia et al., 2000). Amenability to conversion depends largely on the characteristics of the biomass, the substrate and the process requirements (Sonakya et al., 2003) of the technology under investigation. When the $\mathrm{COD} / \mathrm{SO}_{4}$ ratio is greater than $0.67 \mathrm{mg} / \ell$, there is sufficient organic matter to remove sulphate (Hill et al., 1987; Lens et al., 1997; Vallero et al., 2003). However, excessive organic matter resulting in a COD/ $\mathrm{SO}_{4}$ ratio of $>1 \mathrm{mg} / \ell$, can inhibit the sulphidogenic process, thereby favouring methanogenesis. On the other hand, insufficient organic matter provides good conditions for acetogenesis, while excessive acetate in the sulphidogenic reactor can be a limiting factor in biological sulphate reduction (Hill et al., 1987; Lens et al., 1997; Vallero et al., 2003).

In this study the mean $\mathrm{COD} / \mathrm{SO}_{4}$ ratio of $0.55 \mathrm{mg} / \ell$ was measured in the effluent from the continuous reactor. This 


\begin{tabular}{|c|c|c|c|c|c|c|c|c|c|c|}
\hline \multicolumn{11}{|c|}{$\begin{array}{c}\text { TABLE } 1 \\
\text { Chemical composition of the feed and treated water during the periods on reactor }\end{array}$} \\
\hline & \multicolumn{3}{|c|}{ Feed water } & \multirow[b]{2}{*}{$\begin{array}{c}\mathrm{pH} \\
\text { (value) }\end{array}$} & \multicolumn{6}{|c|}{ Treated water } \\
\hline & $\begin{array}{c}\mathrm{pH} \\
\text { (value) }\end{array}$ & $\begin{array}{l}\text { Alkalinity } \\
\text { (value) }\end{array}$ & $\begin{array}{c}\mathrm{SO}_{4} \\
(\mathrm{mg} / \mathrm{l})\end{array}$ & & $\begin{array}{c}\text { COD } \\
(\mathrm{mg} / \mathrm{e})\end{array}$ & \begin{tabular}{|c|} 
Alkalinity \\
(value)
\end{tabular} & $\begin{array}{c}\mathrm{SO}_{4} \\
(\mathrm{mg} / \mathrm{e})\end{array}$ & $\begin{array}{c}\mathrm{S}^{2-} \\
(\mathrm{mg} / \mathrm{e}\end{array}$ & $\begin{array}{l}\text { Redox } \\
(\mathrm{mV})\end{array}$ & $\begin{array}{c}\mathrm{S}^{2} / \mathrm{SO} \\
\text { ratio }\end{array}$ \\
\hline Mean & 7.43 & 175 & 2506 & 7.5 & 1384 & 1276 & 1549 & 180 & -171 & 0.20 \\
\hline Minimum & 7.24 & 134 & 2200 & 6.8 & 560 & 683 & 400 & 44 & -201 & 0.08 \\
\hline Maximum & 7.76 & 270 & 3000 & 8.3 & 3070 & 2556 & 2000 & 340 & -157 & 0.47 \\
\hline Mode & 7.35 & 142 & 2500 & 7.6 & 1814 & 1286 & 1800 & 180 & -168 & 0.20 \\
\hline Median & 7.41 & 146 & 2500 & 7.6 & 1234 & 1176 & 1600 & 180 & -169 & 0.20 \\
\hline
\end{tabular}

\begin{tabular}{|c|c|c|c|c|}
\hline \multicolumn{5}{|c|}{$\begin{array}{c}\text { TABLE } 2 \\
\text { Sulphate removal data in the reactor system }\end{array}$} \\
\hline & $\mathrm{SO}_{4}(\mathrm{mg} / \mathrm{l})$ & $\mathrm{SO}_{4}(\mathrm{~g} / \mathrm{l})$ & $\mathrm{SO}_{4}(\mathrm{~g} / \mathrm{d})$ & $\% \mathrm{SO}_{4}$ removal \\
\hline Mean & 956 & 0.96 & 9.6 & 38 \\
\hline Minimum & 300 & 0.3 & 3 & 14 \\
\hline Maximum & 2100 & 2.1 & 21 & 84 \\
\hline Mode & 1200 & 1.2 & 12 & 48 \\
\hline Median & 900 & 0.9 & 9 & 37 \\
\hline
\end{tabular}

indicates that the SRB started utilising acetate since not sufficient COD was produced. The conditions, thus were favouring the acetogenic process inside the reactor. Although $25 \mathrm{~g}$ of grass was added daily into the continuous reactor, the COD concentration was not sufficient enough to sustain sulphate removal. The expected COD concentration was $25 \mathrm{~g} / \ell$ and with a $\mathrm{SO}_{4}$ concentration of $25 \mathrm{~g} / \ell$, a COD$/ \mathrm{SO}_{4}$ ratio of $1 \mathrm{mg} / \ell$ should have resulted as in the batch test. However, other factors such as poorly degradable lignin available in grass cuttings, and sulphide species may have played a role in low COD concentration.

\section{$\mathrm{SO}_{4}$ removed/sulphide produced ratio}

The produced sulphide concentration is dependent on the $\mathrm{SO}_{4}$ removal rate since sulphate is directly converted to sulphide. Table 1 summarises the sulphide production in the reactor as well as the sulphide/sulphate ratio. Theoretical optimum value sulphide/sulphate ratio of 0.33 has been described by Greben et al. (2007). In this study a mean value of 0.20 was recorded which is low compared to the theoretical value. Some of the reasons for this can be explained by the fact that part of the sulphide escaped in the gaseous form and was not analysed due to lower reactor $\mathrm{pH}$ (Greben et al., 2007). At neutral $\mathrm{pH}$, most of sulphide exists in gaseous form, while at $\mathrm{pH}$ greater than 8 , it is present in ionisable form.

\section{VFA utilisation}

Due to a lower degradation rate of grass cuttings, lower VFA concentrations were noted in the reactor. Figure 9 shows the concentration of butyrate and propionate. A maximum concentration of about $50 \mathrm{mg} / \ell$ butyrate was obtained after sulphate reduction. The propionate concentration produced was immediately utilised in contrast to the butyrate concentration because of its preference as discussed above. The acetate concentration reached a maximum of about $1100 \mathrm{mg} / \ell$ and decreased as a result of utilisation by the SRB (Fig. 9). There was a trend of increasing and decreasing acetate concentration, which was an effect of adding grass, CB and its utilisation by the SRB. Due to lower butyrate and propionate concentration, the SRB were assumed to have utilised acetate as an energy source for sulphate removal. This led to a decreased sulphate removal as SRB grow less favourably on the acetate.

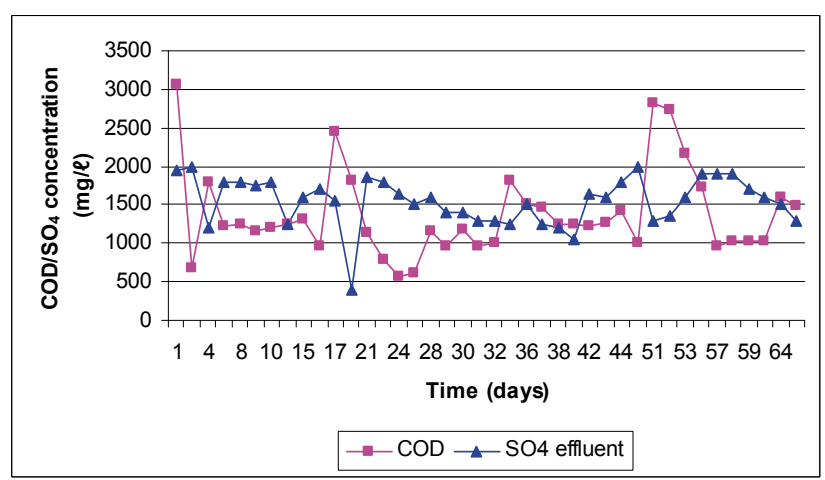

Figure 8

The $\mathrm{COD}$ and $\mathrm{SO}_{4}$ concentration in the reactor effluent

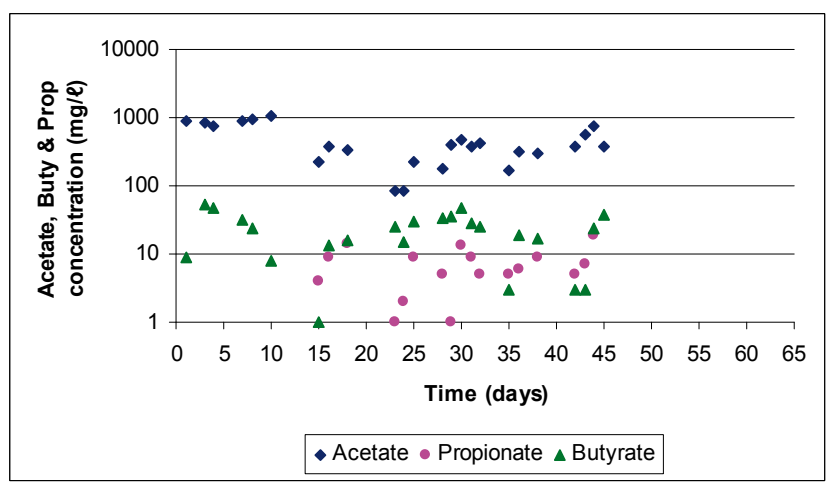

Figure 9

Acetate, propionate and butyrate concentrations in one stage reactor

Other possible reasons why the compost bacteria were unable to efficiently out produce the needed VFA in a one stage reactor could be due to high $\mathrm{pH}$ as a result of sulphate reduction or produced gases during the process inhibited the compost bacteria activity. Perhaps the retention time was too short. The role of $\mathrm{pH}$ has been discussed by other researchers (Zoetemeyer et al., 1982; Veeken et al., 2000), while Moosa et al. (2006) demonstrated that inhibition of biological sulphate reduction is chiefly 
mediated by undissociated hydrogen sulphide $\left(\mathrm{H}_{2} \mathrm{~S}\right)$ species rather than the total sulphide concentration. These aspects will need further investigation.

\section{Conclusions}

The study demonstrated that it is possible to use compost bacteria to degrade cellulose from grass cuttings that in turn provide carbon and energy source for the SRB bacteria in a biological reactor. The performance of the one stage continuous reactor was in the range of 38 to $48 \%$ which needs further investigation.

\section{Acknowledgements}

The authors would like to acknowledge financial support from the National Research Foundation (NRF-THRIP) and the German Academic Exchange Service (DAAD). The Council for Scientific and Industrial Research (CSIR) and BioPAD are thanked for supporting this research. Mrs E. Steyn, Ms J. Baloyi and Mr $\mathrm{R}$ Makhado are accredited for technical assistance and sample analysis.

\section{References}

ASHTON PJ and HAASBROEK B (2000) Water demand management and social adaptive capacity: A South African case study. In: Anthony Turton \& Roland Henwood (eds.) (2002). Hydropolitics in the Developing World: A Southern African Perspective. African Water Issues Research Unit (AWIRU) and International Water Management Institute (IWMI) Pretoria, South Africa. 187-204.

GOTTSCHALK G (1986) Bacterial Metabolism. Springer Verlag, New York, USA, $380 \mathrm{pp}$

GARCIA LBC, RAZO-FLORES E and MONROY O (2007) Performance of a down flow fluidized bed reactor under sulfate reduction using volatile fatty acids as electron donors. Biotechnol. \& Bioeng. 97 771-779.

GREBEN HA, BALOYI LJ and VENTER SN (2007) Grass cellulose as cost-effective energy source for biological sulphate removal. Water SA 33 729-733 http://www.wrc.org.za/downloads/watersa/2007/ Oct $\% 2007 / 2061 . p d f$

GREBEN HA, MAREE JP, SINGMIN Y and MNQANQENI S (2000) Biological sulphate removal from acid mine effluent using ethanol as carbon and energy source. Water Sci. Technol. 42 (3-4) 339-344.
HILL DT, COBBS SA and BOLTE JP (1987) Using volatile fatty acids relationships to predict anaerobic digester failure. Trans. ASAE $\mathbf{3 0}$ 496-501.

HUNGATE RE (1966) The Rumen and Its Microbes. Academic Press Inc, New York, USA, $533 \mathrm{pp}$.

HULSHOFF POL W, LENS PNL, STAMS AJM and LETTINGA G (1998) Anaerobic treatment of sulphate rich waste waters. Biodegrad. 9 214-215.

KALIA VC, SONAKYA V and RAIZADA N (2000) Anaerobic digestion of banana stem waste. Biores. Technol. 73 191-193.

LENS PNL, VAN DEN BOSCH MC, HULSHOFF POL LW and LETTINGA G (1997) Effect of staging on volatile fatty acid degradation in a sulphidogenic granular sludge reactor. Water Res. 32 11781192.

MAREE JP and STRYDOM WF (1985) Biological sulphate removal from a packed bed reactor. Water Res. 19 1101-1106.

MAREE JP, GERBER A and STRYDOM WF (1986) A biological process for sulphate removal from industrial effluent. Water SA 12 $139-144$.

MOOSA S and HARRISON STL (2006) Product inhibition by sulphide species on biological sulphate reduction for the treatment of acid mine drainage. Hydrometall. 83 1-4.

OUDE-ELFERINK SJWH, VISSER A, HULSHOFF POL LW and SLAMS AJM (1994) Sulphate reduction in methanogenic bioreactors. FEMS Microbiol. Rev. 15 119-136.

PICAVET M, DIJKMAN H and BUISMAN C (2001) Development of a novel efficient bioreactor for sulphate reduction. Environ. Agric. Food Chem. 2 297-302.

SONAKYA V, RAIZADA N, DALLHOF R and WILDERER PA (2003) Elucidation mechanism of organic acids production from organic matter (grass) using digested and partially digested cattle feed. Water Sci. Technol. 48 255-259.

STANDARD METHODS (1985) Standard Methods for the Examination of Water and Wastewater. American Public Health Association (APHA), Washington DC. 1268 pp.

VALLERO MVG, LENS PNL, BAKKER C and LETTINGA G (2003) Sulfidogenic volatile fatty acid degradation in a baffled reactor. Water Sci. Technol. 48 81-88.

VEEKEN A, KALYUZHNYI S, SCHARFF H and HAMELERS B (2000) Effect of pH and VFA on hydrolysis of organic solid waste. Environ. Eng. 126 1076-1081.

YOUNGER PL, BANWATT SA and HEDIN RS (2002) Mine Water; Hydrology, Pollution and Remediation. Kluwer Academic Publishers, London, UK. 464 pp.

ZOETEMEYER RJ, VAN DEN HEUVEL JC and COHEN A (1982) $\mathrm{pH}$ influence on acidogenic dissimilation of glucose in an anaerobic digester. Water Res. 16303. 